\title{
Dynamics of Soil Moisture under Different Water Levels and Various Dosages of Organic Fertilizer
}

\author{
Subandi Nur ${ }^{*}$, Suwarto ${ }^{2}$, Saparso ${ }^{2}$ and Heru Adi Djatmiko \\ ${ }^{1}$ Faculty of Agriculture, University of Swadaya, Gunung Jati Cirebon, West Java, Indonesia. ${ }^{2}$ Faculty of \\ Agriculture, Jenderal Soedirman University, Purwokerto Central Java, Indonesia, \\ e-mail: subandi.nur1005@gmail.com
}

Received February 21, 2019; Revised September 3, 2020; Accepted 30 September 2020

\begin{abstract}
The study aimed to determine the dynamics of soil moisture in various standing water levels and dosages of organic fertilizer. The experiment was arranged in a Completely Randomized Block Design (CRBD) with a $3 \times 3$ factorial treatment in 3 replicates. The first factor was 3 different water levels, namely $10 \mathrm{~cm}$ (T1), $20 \mathrm{~cm}$ (T2), and 30 $\mathrm{cm}$ (T3). The second factor was 3 levels of dosages of organic fertilizer, namely $0 \mathrm{~g} \mathrm{pot}^{-1}(\mathrm{P} 1), 35 \mathrm{~g} \mathrm{pot}^{-1}(\mathrm{P} 2)$, and 70 $\mathrm{g} \mathrm{pot}^{-1}(\mathrm{P} 3)$. The highest of soil moisture was obtained in the $10 \mathrm{~cm}$ water levels and $70 \mathrm{~g}$ organic fertilizer (T1P3) and the lowest in the $30 \mathrm{~cm}$ water levels and without organic fertilizer (T3P1). The highest infiltration rate was obtained in the $30 \mathrm{~cm}$ water levels and $70 \mathrm{~g} \mathrm{pot}^{-1}$ organic fertilizer (T3P3), the $30 \mathrm{~cm}$ water levels and $35 \mathrm{~g} \mathrm{pot}^{-1}$ organic fertilizer (T3P2), the $20 \mathrm{~cm}$ water levels and $70 \mathrm{~g} \mathrm{pot}^{-1}$ organic fertilizer (T2P3), and the lowest in the combination of the $10 \mathrm{~cm}$ water levels and without organic fertilizer (T1P1). The highest capillary rate was obtained in the combination of the $30 \mathrm{~cm}$ water levels and $70 \mathrm{~g}$ organic fertilizer (T3P3) and the lowest in the combination of the $30 \mathrm{~cm}$ water levels and without organic fertilizer (T3P1).
\end{abstract}

Keywords: Organic fertilizer, soil moisture, water level

\begin{abstract}
ABSTRAK
Tujuan penelitian adalah untuk mengetahui pengaruh perlakuan tinggi permukaan air genangan dan dosis pupuk organik terhadap lengas tanah, laju infiltrasi dan laju kapiler. Percobaan dilasanakan pada bulan Agustus sampai Oktober 2017 di Laboratorium Fakultas Pertanian Universitas Swadaya Gunung Jati Cirebon Jawa Barat. Perlakuan pada percobaan ini menggunakan rancangan acak kelompok yang disusun dalam pola faktorial terdiri dari dua faktor dan tiga ulangan. Faktor pertama adalah tinggi permukaan air genangan (T) terdiri dari tiga taraf, yaitu T1 (10 $\mathrm{cm}), \mathrm{T} 2(20 \mathrm{~cm}), \mathrm{T} 3(30 \mathrm{~cm})$ dan faktor kedua adalah pupuk organik $(\mathrm{P})$ terdiri dari tiga taraf, yaitu P1: $0 \mathrm{~g} \mathrm{pot}^{-1}, \mathrm{P} 2$ : $70 \mathrm{~g} \mathrm{pot}^{-1}$, dan P3: $140 \mathrm{~g} \mathrm{pot}^{-1}$. Variabel yang diamati adalah kelembaban tanah, laju infiltrasi dan laju kapiler. Hasil penelitian menunjukkan bahwa terjadi interaksi antara tinggi permukaan air genangan dengan dosis pupuk organik terhadap kelembaban tanah. Aplikasi tinggi permukaan air genangan pada berbagai taraf dosis pupuk organik memberikan pengaruh yang lebih baik terhadap lengas tanah, laju infiltrasi dan laju kapiler. Lengas tanah tertinggi diperoleh pada kombinasi perlakuan T1P3 dan terendah T3P1, laju infiltrasi tertinggi diperoleh pada kombinasi perlakuan T3P3 dan terendah T1P1 adapun laju kapiler tertinggi diperoleh pada kombinasi perlakuan T3P3 dan terendah pada kombinasi perlakuan T3P1.
\end{abstract}

Kata Kunci: Air genangan, pupuk organik, lengas tanah

\section{INTRODUCTION}

A steady source of water for developing and growing of plants is needed since plants need high water, so that water is so important for plant growth.

J Trop Soils, Vol. 25, No. 3, 2020: 157-164

ISSN 0852-257X; E-ISSN 2086-6682
If the amount of groundwater is less, the plant growth will be restricted due to water is a staple of photosynthesis and the transportation of plant nutrients (Gardner et al. 1991, Salisbury and Ross 1995; Utomo et al. 2016). The movement of water comes from a place that has a lot of humidity towards a place that has less soil moisture (Asdak 2010). In certain soil volumes, there is movement of water 
through the soil pore space caused by gravitational and capillary forces. If soil moisture is optimum for plant growth, a large amount of water in the intermediate-sized pore space in the soil can move and can be used by plants. The ability of plants to obtain water is determined by several things, including the ability of plant roots to absorb, the use of water in contact, and the speed of groundwater moves to replace the water used by plants (Rassyid et al. 2010; Nio and Torey 2013). According to Fauziah et al. (2015), the provision of water by irrigation has a better effect than conventional methods. Efficient irrigation must be provided to maintain growth for plants that have shallow root systems, this is because these plants are very vulnerable to loss of water from the topsoil (Patel and Rajput 2013).

Excessive fertilization for a long time, instead of improving soil structure and fertility, will cause severe soil degradations, which are characterized by high acidity, low nutrition, and disturbed ecosystem balance. An alternative step to overcome the crisis of incentive agriculture is an organic farming system (Dong et al. 2012; Parwi et al. 2019).

Various ways can be done to build an organic farming system, one of which by using organic fertilizers. In soil management, one of the most important materials is organic matter. The presence of organic matter is also one of the parameters in determining the class of land productivity. Organic matters affect soil aggregation, water infiltration, water content, drainage, watering, temperature, microbial activity, and root penetration which are very suitable for plant growth. Organic matters can play a role, among others: firstly, carbon sources for microorganisms; secondly, together with microorganisms form the soil structure so that it can form a stable soil aggregate; thirdly, increase water holding capacity; fourthly, increase CEC and reduce $\mathrm{pH}$; fifthly, nutrients $\mathrm{N}, \mathrm{P}$, and $\mathrm{S}$ are available for plants; and finally, reduce the danger of poisoning with metals or compounds that are toxic to living bodies (Zhen et al. 2014; Hasibuan 2015; Utomo et al. 2016). The activity of soil organisms can be increased by adding organic matter to the soil and in turn, soil fertility can be improved and maintained (Subowo 2010).

Organic matters provide many benefits to the soil because it can provide nutrients through mineralization, increase cation exchange capacity, water retention capacity and improve soil physical characteristics, reduce soil erosion and water leaching (Dhaker et al. 2017; Sunaryaand Sumarsih
2017). According to Zhou et al. (2013), there are several direct effects of organic matter on plants, namely the presence of free carbon dioxide is beneficial in photosynthesis, the presence of some chemical compounds that can stimulate plant growth, and the production of amino acids which can be immediately absorbed by the roots.

Organic matters can improve the physical, biological and chemical conditions of soil as a growing medium. It can improve soil aeration and soil moisture, provide soil nutrients, and a source of energy for microorganisms. The biggest role of organic matter is in soil physical properties. Soil that contains sufficient organic matter will have a relatively better soil condition so that there will be no significant difficulties in soil cultivation. An increase in soil porosity is another effect of organic matter on soil physical properties. The part of the land that is not filled with solid soil but is filled with air and water affect the porosity of the soil. Micro pores are known as capillary pores, mesopores are known as slow drainage pores and macropores are known as fast drainage pores. The ability of soil to hold water can be increased by adding organic matter, so that water for plant growth is available, this is because the soil can provide water (Suntoro 2003; Liu et al. 2013).

This research aimed to study the effect of various water surface height and dosage of organic fertilizers on soil moisture, infiltration rate, and capillary rate. As a study for the cultivation of shallots in areas that generally use raised beds with a certain depth of trench.

\section{MATERIALS AND METHODS}

\section{Research Site and Design}

The research was conducted in the field and laboratory of the Faculty of Agriculture, Swadaya Gunung Jati University, Cirebon, West Java, Indonesia.

This study used a completely randomized block design (CRBD) which was arranged factorial. The first factor was the inundation water surface which consists of three (3) levels, namely $\mathrm{T} 1=10 \mathrm{~cm}$ from the bottle surface, $\mathrm{T} 2=20 \mathrm{~cm}$ from the bottle surface and $\mathrm{T} 3=30 \mathrm{~cm}$ from the bottle surface. While, the second factor was the dosage of organic fertilizer which consisted of three (3) levels, namely $\mathrm{P} 1=0 \mathrm{~g}, \mathrm{P} 2=35 \mathrm{~g}$, and $\mathrm{P} 3=70 \mathrm{~g}$. Thus there were 9 treatment combinations, and each treatment combination was repeated 3 times so that 27 experimental units were obtained. 


\section{Research Implementation and Data Recording}

Materials and tools used included soil, organic fertilizer, water, buckets, transparent plastic bottles $40 \mathrm{~cm}$ long and $10 \mathrm{~cm}$ in diameter. The bottle had eight holes on it from eight sides with a height of 10 $\mathrm{cm}, 20 \mathrm{~cm}$, and $30 \mathrm{~cm}$ from the bottom of the bottle. The bottle was filled with media soil of approximately $4.5 \mathrm{~kg}$ and organic fertilizer then put into a bucket that already contained water according to the treatment.

Soil moisture was quantified gravimetrically at a depth of $5 \mathrm{~cm}$. Infiltration rate was determined by pouring a certain volume of water in each trial bottle and noted the time needed, while the capillary rate was determined by inserting a trial bottle that had been perforated according to the treatment into the bucket which already contained water with the depth according to treatment and recorded the time needed for the water to reach the surface of the bottle.

\section{Data Analysis}

The data were analyzed by analysis of variance (ANOVA) at the significance level of $5 \%$ and continued by post hoc analysis using Least Significant Differences (LSD) test at the significance level of $5 \%$.

\section{RESULTS AND DISCUSSION}

The results of the analysis of variance showed that the interaction between the water level and the dose of organic fertilizer significantly affected the soil moisture. Standing water level showed various effects in soil moisture, infiltration rate, and capillary rate. The dose of organic fertilizer also affected soil moisture, infiltration rate, and capillary rate (Table 1).

\section{Soil Moisture}

The results of the LSD test at the level of 5\% on soil moisture, infiltration rate, and capillary rate

Table 1.Results of analysis of variance of observed variables.

\begin{tabular}{llllc}
\hline No & Variables & $\mathrm{T}$ & $\mathrm{P}$ & $\mathrm{T} \times \mathrm{P}$ \\
\hline 1. & Soil Moisture & $* *$ & $* *$ & $* *$ \\
2. & Infiltration Rate & $* *$ & $* *$ & $\mathrm{~ns}$ \\
3. & Capillary Rate & $* *$ & $* *$ & $\mathrm{~ns}$ \\
\hline
\end{tabular}

Note: $\mathrm{ns}=$ not significant, $* *=$ very significant after testing $\mathrm{F} 1 \%, \mathrm{~T}=$ standing water level, $\mathrm{P}=$ the dose of organic fertilizer.

Table 2. Effect of water levels and organic fertilizer dose on the soil moisture, infiltration rate and capillary rate.

\begin{tabular}{cccc}
\hline Treatment & $\begin{array}{c}\text { Soil Moisture } \\
(\%)\end{array}$ & $\begin{array}{c}\text { Infiltration Rate } \\
\left(\mathrm{cm} \mathrm{hr}^{-1}\right)\end{array}$ & $\begin{array}{c}\text { Capillary Rate } \\
\left(\mathrm{cm} \mathrm{hr}^{-1}\right)\end{array}$ \\
\hline T1P1 & $24.24 \mathrm{c}$ & $10.13 \mathrm{a}$ & $6.43 \mathrm{~b}$ \\
T1P2 & $26.75 \mathrm{e}$ & $11.30 \mathrm{~b}$ & $6.70 \mathrm{c}$ \\
T1P3 & $32.66 \mathrm{~g}$ & $11.98 \mathrm{c}$ & $6.93 \mathrm{~d}$ \\
T2P1 & $23.03 \mathrm{~b}$ & $11.36 \mathrm{~b}$ & $6.67 \mathrm{c}$ \\
T2P2 & $25.30 \mathrm{~d}$ & $11.55 \mathrm{~b}$ & $7.20 \mathrm{e}$ \\
T2P3 & $30.93 \mathrm{f}$ & $12.75 \mathrm{~d}$ & $7.20 \mathrm{e}$ \\
T3P1 & $16.58 \mathrm{a}$ & $11.95 \mathrm{c}$ & $6.33 \mathrm{a}$ \\
T3P2 & $24.12 \mathrm{c}$ & $12.86 \mathrm{~d}$ & $7.50 \mathrm{f}$ \\
T3P3 & $26.79 \mathrm{e}$ & $12.94 \mathrm{~d}$ & $7.83 \mathrm{~g}$ \\
\hline
\end{tabular}

Description: T1P1 = Standing Water Level $10 \mathrm{~cm}+$ Organic Fertilizer $0 \mathrm{~g}$; T1P2= Standing water level $10 \mathrm{~cm}+$ organic fertilizer $35 \mathrm{~g} \mathrm{pot}^{-1} ; \mathrm{T} 1 \mathrm{P} 3=$ Standing water level $10 \mathrm{~cm}+$ organic fertilizer $70 \mathrm{~g} \mathrm{pot}^{-1} ; \mathrm{T} 2 \mathrm{P} 1=$ Standing water level $20 \mathrm{~cm}+$ organic fertilizer 0 $\mathrm{g} ; \mathrm{T} 2 \mathrm{P} 2=$ Standing water level $20 \mathrm{~cm}+$ organic fertilizer $35 \mathrm{~g} \mathrm{pot}^{-1} ; \mathrm{T} 2 \mathrm{P} 3=$ Standing Water Level $10 \mathrm{~cm}+$ organic fertilizer $70 \mathrm{~g} \mathrm{pot}^{-1} ; \mathrm{T} 3 \mathrm{P} 1=$ Standing Water Level $30 \mathrm{~cm}$ + organic fertilizer $0 \mathrm{~g}$; T3P2= Standing Water Level $30 \mathrm{~cm}+$ Organic Fertilizer $35 \mathrm{~g}$ pot $^{-1} ;$ T3P3 $=$ Standing Water Level $30 \mathrm{~cm}+$ organic fertilizer $70 \mathrm{~g} \mathrm{pot}^{-1}$. 
as affected by water level and dose of organic fertilizer are presented in Table 2 .

Soil moisture by the combination of water level and the dose of organic fertilizer treatment was not significantly different between $\mathrm{T} 1 \mathrm{P} 1$ and $\mathrm{T} 3 \mathrm{P} 2$ (Table 2). While other treatment combinations differed significantly from one to another. The highest of soil moisture was obtained in the combination of T1P3 and the lowest was in the combination of T3P1. This situation was possible because T1P3 was a treatment combination that had the surface of the bottle (the field) closest to the water source so that the movement of water from the source to the field was relatively faster. Thus at the same time, the humidity level of T1P3 was relatively higher compared to other treatments. Asdak (2010) said that water would move from moist soil to drier soil. On moist soil, the amount of water percentage was higher and the displacement was faster. Besides, the amount of organic fertilizer with higher doses would also improve the soil structure, so that the T1P3 absorbed more water than any other treatment. This was following Suntoro (2003), that organic matter played a role, among others, on soil structure, consistency, porosity, and holding water. It was also said by Eko (2007) and Sunarya and Suyudi (2016) that the more organic matter content caused the water in the soil to multiply.

Likewise, in a single treatment, both water levels, and organic fertilizer doses. The main effect of standing water level on soil moisture can be seen in Table 3. The effect of treatment (T1, T2, and T3) was significantly different where $\mathrm{T} 1$ was the treatment that produced the highest soil moisture followed by $\mathrm{T} 2$ and $\mathrm{T} 3$. This was probably due to the treatment of the T1 layer in the field or soil surface was closer to the water source compared to the treatment of $\mathrm{T} 2$ and $\mathrm{T} 3$ so that the treatment had the highest humidity compared to the other treatments at the same time. Craig (1991) said that water would move from moist soil to drier soil. On moist soil, the amount of water percentage was higher and the displacement was faster. The effect of organic fertilizer dose can be seen in Table 4 that each treatment (P1, P2, and P3) was significantly different where $\mathrm{P} 3$ was the treatment that produced the highest soil moisture followed by $\mathrm{P} 2$ and $\mathrm{P} 1$. This was likely because the amount of organic fertilizer with higher doses would affect the soil structure, so that the P3 treatment absorbed water more than other treatments (P2 and P1). This was following Suntoro (2003), that organic matter played a role, among others, on soil structure, consistency, porosity, and binding water capacity. It was also said by Eko (2007) and Sunarya and Suyudi (2016) that, the more organic matter content caused the water in the soil to multiply.

\section{Infiltration Rate}

The results of the LSD test at $5 \%$ level on the infiltration rate due to treatment of standing water

Table 3. The soil moisture, infiltration rate, and capillary rate under different water levels.

\begin{tabular}{cccc}
\hline Treatment & $\begin{array}{c}\text { Soil Moisture } \\
(\%)\end{array}$ & $\begin{array}{c}\text { Infiltration Rate } \\
\left(\mathrm{cm} \mathrm{hr}^{-1}\right)\end{array}$ & $\begin{array}{c}\text { Capillary Rate } \\
\left(\mathrm{cm} \mathrm{hr}^{-1}\right)\end{array}$ \\
\hline T1 & $27.88 \mathrm{c}$ & $11.14 \mathrm{a}$ & $6.69 \mathrm{a}$ \\
T2 & $26.42 \mathrm{~b}$ & $11.89 \mathrm{~b}$ & $7.02 \mathrm{~b}$ \\
T3 & $22.49 \mathrm{a}$ & $12.58 \mathrm{c}$ & $7.22 \mathrm{c}$ \\
\hline
\end{tabular}

Description: $\mathrm{T} 1=$ Standing water level $10 \mathrm{~cm}$; $2=$ Standing water level $20 \mathrm{~cm}$; $3=$ Standing water level $30 \mathrm{~cm}$.

Table 4. The soil moisture, infiltration rate, and capillary under different doses of organic fertilizer.

\begin{tabular}{cccc}
\hline Treatment & $\begin{array}{c}\text { Soil Moisture } \\
(\%)\end{array}$ & $\begin{array}{c}\text { Infiltration Rate } \\
\left(\mathrm{cm} \mathrm{hr}^{-1}\right)\end{array}$ & $\begin{array}{c}\text { Capillary Rate } \\
\left(\mathrm{cm} \mathrm{hr}^{-1}\right)\end{array}$ \\
\hline P1 & $21.28 \mathrm{a}$ & $11.15 \mathrm{a}$ & $6.48 \mathrm{a}$ \\
P2 & $25.39 \mathrm{~b}$ & $11.90 \mathrm{~b}$ & $7.13 \mathrm{~b}$ \\
P3 & $30.13 \mathrm{c}$ & $12.56 \mathrm{c}$ & $7.32 \mathrm{c}$ \\
\hline
\end{tabular}

Description: P1= Organic Fertilizer $0 \mathrm{~g}$; P2= Organic fertilizer $35 \mathrm{~g} \mathrm{pot}^{-1} ; \mathrm{P} 3=$ Organic fertilizer $70 \mathrm{~g} \mathrm{pot}^{-1}$. 
level and dosage of organic fertilizer are presented in Table 2.

As seen in Table 2, the infiltration rate by the treatment of standing water level and the dose of organic fertilizer was significantly higher at T1P1 than other treatments. While T1P2 treatment was not significantly different from $\mathrm{T} 2 \mathrm{P} 1$ and $\mathrm{T} 2 \mathrm{P} 2$, but it was significantly different from T1P3, T2P3, T3P1, T3P2, and T3P3. Likewise, T1P3 was not significantly different from T3P1, but it was significantly different from other treatments. T2P3 was not significantly different from T3P2 and T3P3 but was significantly different from other treatments. The highest infiltration rate was obtained as affected by T3P3, T3P2, and T2P3 while the lowest was obtained in T1P1. This was a possibility that T1P1 had a soil condition with the highest relative humidity and a relatively denser soil structure compared to other treatments, so the infiltration rate was relatively lowest compared to other treatments. This was by Utomo et al. (2016), the rate of infiltration was strongly affected by several factors, one of which was soil factors, such as texture, structure, aggregate stability, soil compaction, and soil moisture content. The amount of soil moisture in the upper layer greatly influenced the infiltration rate, so that the greater the soil water content, the less infiltration capacity would be (Hari 2010). Also, Sri Puspita Sari et al. (2012) stated that the denser the soil and the higher the water content in the soil, the faster the infiltration rate of the soil. The highest infiltration rate was obtained from T3P3, this was probably because the treatment formed a relatively low soil moisture condition and relatively more pore numbers compared to other treatments. According to Hari (2010), the amount of soil water content and soil pore rate greatly influenced the infiltration rate, the amount of soil water content would reduce infiltration capacity while the magnitude of the pore number would accelerate the rate of infiltration. Babbu et al. (2015) also stated that the application of fertilizers could affect the physical properties of soil directly or indirectly, such as aggregate stability, water holding capacity, porosity, and infiltration rate.

Likewise, the infiltration rate was every 20 minutes. In Figure 1, the infiltration rate in the treatment of water level with organic fertilizer dose every 20 minutes had decreased. In the first 20 minutes, the infiltration rate was relatively faster (average over $4000 \mathrm{~mm} \mathrm{day}^{-1}$ ), and as the infiltration rate increased slowly, in the 100th minute the

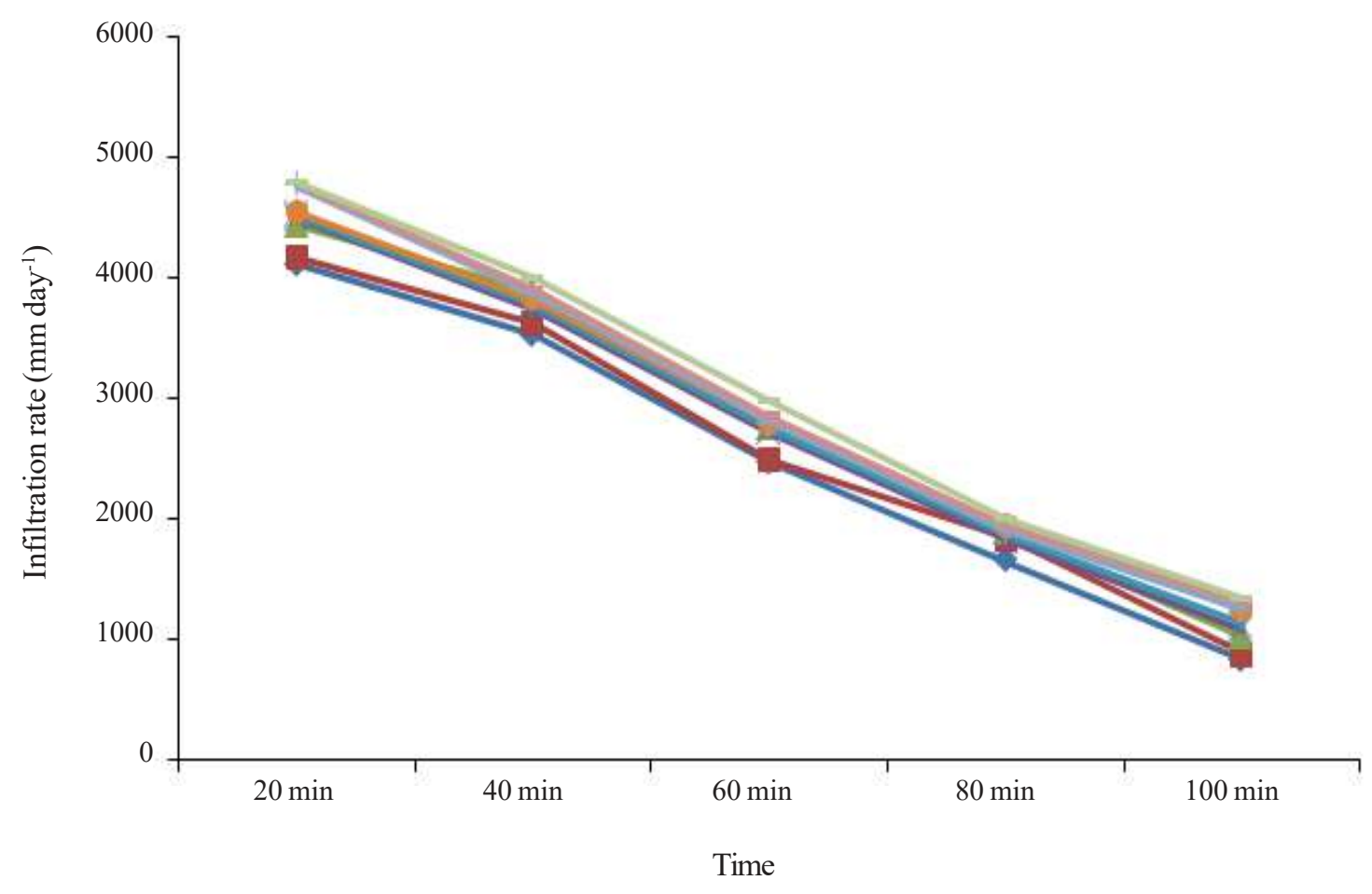

Figure 1. Infiltration rate in the treatment of water level and organic fertilizer dose every 20 minutes (mm

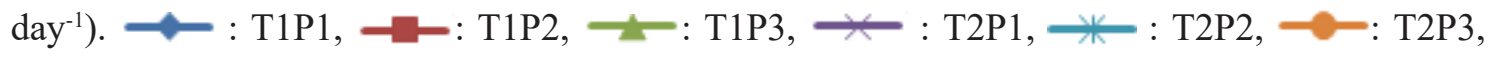
: T3P1, $:$ T3P2, : T3P3. 
infiltration rate was only around $1000 \mathrm{~mm}$ day $^{-1}$. The highest infiltration rate in $\mathrm{T} 3 \mathrm{P} 3$, at the 20th minute, was as high as $4,790 \mathrm{~mm}$ day $^{-1}$ and in the 100th minute as high as $1,344 \mathrm{~mm} \mathrm{day}^{-1}$. The lowest was T1P1 in the 20th minute was as high as $4,116 \mathrm{~mm}$ day $^{-1}$ and in the 100th minute was as high as 823 $\mathrm{mm}$ day $^{-1}$.

On a single effect, the standing water level had effects on the infiltration rate (Table 3), that each treatment (T1, T2, and T3) was significantly different, and $\mathrm{T} 3$ was the treatment that produced the highest infiltration rate followed by $\mathrm{T} 2$ and $\mathrm{T} 1$. This was probably because $\mathrm{T} 1$ has a relatively higher humidity level compared to T2 and T3, so the infiltration rate in the $\mathrm{T} 1$ was lower compared to $\mathrm{T} 2$ and T3. This condition was by Hari (2010), that the amount of soil water content and pore number greatly affected the rate of infiltration, where the amount of soil water content would reduce infiltration capacity.
The effect of organic fertilizer dose could be seen in Table 4, that each treatment (P1, P2, and P3) was significantly different, and P3 was the treatment that produced the highest infiltration rate followed by $\mathrm{P} 2$ and P1. This condition was suspected because the dose of $\mathrm{P} 3$ was the highest compared to P2 and P1 treatments. This was following Utomo et al. (2016), that organic matter could affect the physical properties of soil through improving aggregation. Land with good aggregation would increase the infiltration rate which could reduce surface flow and erosion, a good soil aeration system where gas exchange with the atmosphere was fast and facilitated penetration of plant roots in the soil.

\section{Capillary Rate}

The results of the LSD at the level of $5 \%$ on the Capillary Rate as affected by the treatment of

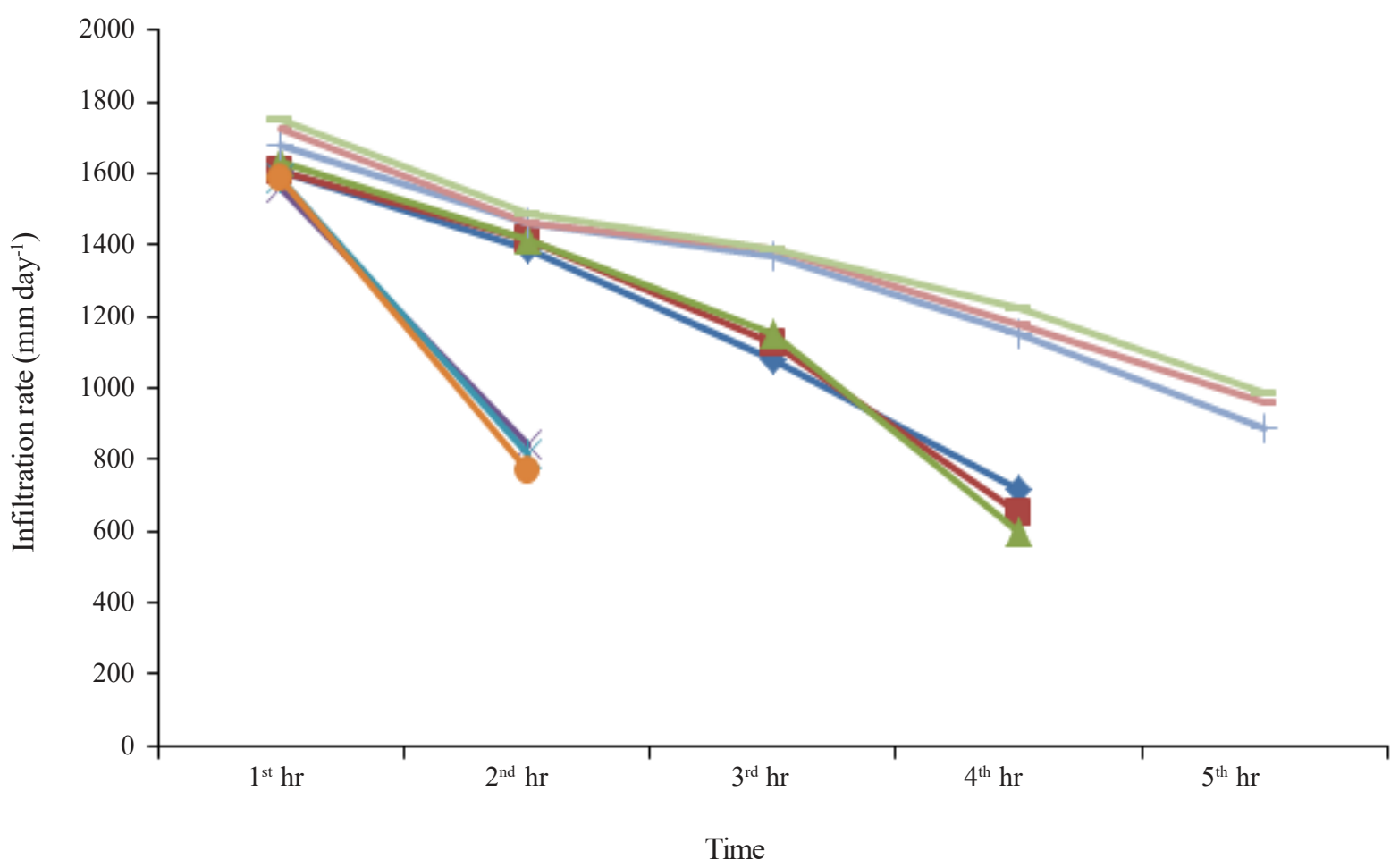

Figure 2. Capillary rate under treatment of standing water level and organic fertilizer dose from hour to hour

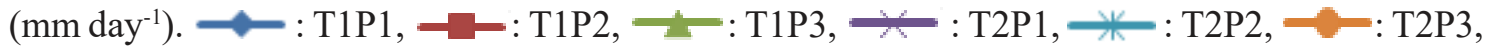
$\longrightarrow$ : T3P1, — : T3P2, — : T3P3. Description: T1P1= Standing water level $10 \mathrm{~cm}+$ Organic fertilizer $0 \mathrm{~g}$; T1P2= Standing water level $10 \mathrm{~cm}+$ Organic fertilizer $35 \mathrm{~g} \mathrm{pot}^{-1} ; \mathrm{T} 1 \mathrm{P} 3=$ Standing water level $10 \mathrm{~cm}+$ Organic fertilizer $70 \mathrm{~g} \mathrm{pot}^{-1}$; T2P1 $=$ Standing water level $20 \mathrm{~cm}+$ organic fertilizer $0 \mathrm{~g} ; \mathrm{T} 2 \mathrm{P} 2=$ Standing water level $20 \mathrm{~cm}+$ Organic fertilizer $35 \mathrm{~g} ; \mathrm{T} 2 \mathrm{P} 3=$ Standing water level $10 \mathrm{~cm}+$ organic fertilizer $70 \mathrm{~g} \mathrm{pot}^{-1}$; T3P1= Standing water level $30 \mathrm{~cm}+$ Organic fertilizer $0 \mathrm{~g}$; T3P2 $=$ Standing water level $30 \mathrm{~cm}+$ Organic fertilizer $35 \mathrm{~g} \mathrm{pot}^{-1} ; \mathrm{T} 3 \mathrm{P} 3=$ Standing water level $30 \mathrm{~cm}+$ Organic fertilizer $70 \mathrm{~g} \mathrm{pot}^{-1}$. 
standing water level and dose of organic fertilizer were presented in Table 2.

In Table 2, the capillary rate by the combination treatment of water level and an organic fertilizer dose was not significantly different between T1P2 and T2P1 as well as between T2P2 and T2P3. While the other treatment combinations differed significantly from each other, namely T1P1, T1P2, T1P3, T2P2, T3P1, T3P2, and T3P3. The highest capillary rate was obtained in $\mathrm{T} 3 \mathrm{P} 3$ and the lowest in the T3P1. This condition was suspected because T3P3 affected the soil relatively had lower humidity and relatively more pore numbers compared to other treatments. Amrizal (2006) stated that, when groundwater was not saturated, the capillary force on the soil was greater. This was consistent with the statement of Dani and Rath (2000) that, land with a greater capillary rate was soil that had a non-dense structure and many pores.

Likewise, the capillary rate in every one hour (60 minutes). In Figure 2, the capillary rate in the treatment of standing water level with a dose of organic fertilizer every one hour (60 minutes) had decreased rate. At the first hour (60 minutes) the capillary rate was relatively fast, which averaged above $1,500 \mathrm{~mm}$-days and was slower with increasing time. The highest capillary rate was at T3P3 and the lowest one was at T1P1.

As seen in Table 3, the single effect of standing water level on capillary rate was significantly different, and T3 was the treatment that produced the highest capillary rate followed by $\mathrm{T} 2$ and $\mathrm{T} 1$.

Likewise, the effect of a single dose of organic fertilizer on capillary rate could be seen in Table 4, which was significantly different where P3 was a treatment that produced the highest capillary rate followed by $\mathrm{P} 2$ and $\mathrm{P} 1$. This condition was suspected because the soil moisture in each treatment was different, causing the capillary rate for each treatment to be different. This was following Amrizal (2006), that when optimum soil moisture for plant growth was attained, then a large amount of water in intermediate-sized pore space in the soil could move and could be used by plants.

\section{CONCLUSIONS}

The highest of soil moisture was obtained in the T1P3 $(10 \mathrm{~cm}$ water levels and $70 \mathrm{~g}$ organic fertilizer) treatment and the lowest in the T3P1 treatment $(30 \mathrm{~cm}$ water levels and without organic fertilizer). The highest infiltration rate was obtained in the T3P3 treatment $(30 \mathrm{~cm}$ water levels and $70 \mathrm{~g}$ organic fertilizer) while the lowest was obtained in the T1P1 treatment $(10 \mathrm{~cm}$ water levels and without organic fertilizer). The highest capillary rate was obtained in the T3P3 treatment combination and the lowest in the T3P1 treatment combination. The single effect of standing water level at soil moisture, T1 $(10 \mathrm{~cm}$ water levels) was the treatment that produced the highest of soil moisture followed by T2 $(20 \mathrm{~cm}$ water levels) and T3 (30 cm water levels). At the infiltration rate, $\mathrm{T} 3$ was the treatment that produces the highest infiltration rate followed by T2 and $\mathrm{T} 1$. And at the capillary rate, T3 was the treatment that produces the highest capillary rate followed by $\mathrm{T} 2$ and $\mathrm{T} 1$. The single effect of each organic fertilizer dose, P3 (70 g organic fertilizer) was the treatment that produced the highest of soil moisture followed by P2 (35 g organic fertilizer) and P1 (0 g organic fertilizer). For the infiltration rate, $\mathrm{P} 3$ was the treatment that produced the highest infiltration rate followed by P2 and P1. The capillary rate of each treatment was significantly different, and P3 was the treatment that produced the highest capillary rate followed by P2 and P1.

\section{ACKNOWLEDGMENTS}

We are very grateful to the post-graduate supervisor of Faculty of Agriculture, University of Soedirman Purwokerto, Central Java Indonesia, Head of the Experimental and Field Laboratory, and students of Faculty of Agriculture, Unswagati, Cirebon, West Java, Indonesia.

\section{REFERENCES}

Amrizal S. 2006. Fisika Tanah dan Lingkungan. Andalas University Press. Padang. (in Indonesian).

Asdak C. 2010. Hidrologidan Pengelolaan Daerah Aliran Sungai.Gajah Mada University Press. Yogyakarta. (in Indonesian).

Babbu SB, S Jagdeep, S Gurbir and K Gurpreet. 2015. Effect of long term application of inorganic and organic fertilizer on soil Organicarbon and physical properties in maize-wheat rotation. Agronomy 5: 220-238. doi : 10.3390/agronomy5020220.

Dani OR and JM Rath. 2000. Water Movement in Soil. In: ME Summer (ed). Hand Book of Soil Sience CRC Press. Boca Raton-London-New York- Washington DC. P. A 53-A 86.

Dhaker B, RK Sharma, BG Chipa and RS Rathore. 2017. Effect of different organic manures on yield and quality of onion (Allium cepa L.). Int $J$ Curr Microbiol Appl Sci 6: 3412-3417.

Dong W, X Zhang, H Wang, X Sun, W Qiu and F Yang. 2012. Effect of different fertilizer application on the soil fertility of paddy soils in red soil region of Southern China. Plos One 7: e44504. doi: https:// doi.org/10.1371/journal.pone.0044504 
Eko M. 2007. Pengaruh bahan organik terhadap kadar air tanah dan pertumbuhan tanaman jagung di lahan kering. Buana Sains 7: 51-60. (in Indonesian).

Fauziah R, AD Susila and E Sulistiono. 2016. Budidaya bawang merah (Allium ascalonicum L.) pada lahan kering menggunakan irigasi sprinkler pada berbagai volume dan frekuensi. J Hort Indonesia 7: 1-8. (in Indonesian).

Gardner FP, RB Pearce and RL Mitchel. 1991. Physiology of Crop Plant. (Terjemahan Susilo H. 1991. Fisiologi Tanaman Budidaya).Universitas Indonesia-Press.

Hari W. 2010. Laju infiltrasi pada lahan gambut yang dipengaruhi air tanah (Study Kasus Sei Raya Dalam Kecamatan Sei Raya Kabupaten Kubu Raya). J Belian 9: 90-103.

Hasibuan ASZ. 2015. Pemanfaatan bahan organik dalam perbaikan beberapa sifat tanah pasir pantai selatan Kulon Progo. Planta Tropika J Agro Sci 3: 31-40. doi : 10.18196/pt.2015.037.

Liu E, C Yan, X Mei, Y Zhang and T Fan. 2013. Long-term effect of manure and fertilizer on soil organic carbon pool in dryland farming in Northwest China. Plos One 8: e56536. doi: 10.1371/journal. pone. 0056536.

Nio SA and P Torey. 2013. Karakter morfologi akar sebagai indikator kekurangan air pada tanaman (Root morphological characters as water-deficit indicators in plants). J Bios Logos 3: 31-39. doi https://doi.org/ 10.35799/jbl.3.1.2013.3466

Parwi, U Isnatin, M Hamawi and U Etica. 2019. Growth and yield of Sshallot (Allium cepa L.) in respon of organic fertilizers and Trichoderma asperellum. $J$ Phys: Conf Ser 1381 012004. doi:10.1088/1742-6596/ 1381/1/012004.

Patel N and TBS Rajput. 2013 Effect of deficit irrigation on crop growth, yield and quality of onion in subsurface drip irrigation. Int J Plant Produc 7: 417-436.
Salisbury FB and CW Ross. 1995. FisiologiTumbuhan. Institut Teknologi Bandung. Bandung. (in Indonesian).

Sri PS, Sumono, N Ichwan and E Susanto. 2012. Kajian laju infiltrasi tanah pada berbagai penggunaan lahan di Desa Tanjung Putus Kecamatan Padang Tualang Kabupaten Langkat. J Rekayasa Pangan dan Pertanian 1: 115-119.

Subowo G. 2010. Strategi efesiensi penggunaan bahan organik untuk kesuburan dan produktivitas tanah melalui pemberdayaan sumberdaya hayati tanah. $J$ Sumberdaya Lahan 4: 13-25.

Sunarya Y and Suyudi. 2016. Pengaruh Pupuk Organik dan Kelembaban tanah terhadap pertumbuhan tanaman mendong (Fymbristylisglobulosa (Retz) Kunt). J Siliwangi - Seri Sains dan Teknologi 2: 96-100.

Sunarya Y and E Sumarsih. 2017. The effect of soil moisture content an animal manure application on the growth of mendong (Fimbristylis globulosa (Retz) Kunt). J Trop Soils 22: 107-112. doi: 10.5400/ jts.2017.22.2.107.

Suntoro WA. 2003. Peranan Bahan Organik terhadap Kesuburan Tanah dan Upaya Pengelolaannya. Sebelas Maret University Press. Surakarta, 36 p.

Utomo M, S Tengku, Sudarsono, J Lumbanraja, R Bujang and Wawan. 2016. Ilmu Tanah Dasar Dasar dan Pengelolaannya. Prenada Media Group. Jakarta,

Zhou H, X Peng, E Perfect, T Xiao and G Peng. 2013. Effect of organic and inorganic fertilization on soil aggregation in an ultisol as characterized by Synchroton Based X - Ray Micro-Computed Tomography. Geoderma 195-196: 23-30.

Zhen Z, H Liu, Na Wang, L Guo, J Meng, Na Ding, G Wu and G Jiang. 2014. Effects of manure compost application on soil microbial community diversity and soil microenvironments in a temperate cropland in China. Plos One 9: e108555. doi: $0.1371 /$ journal.pone.0108555. 